Çeliktürk Sezgin, Z. ve Gedikoğlu Özilhan, Y. G. (2019). 1.-8. Sınıf Türkçe ders kitaplarındaki metne dayalı anlama sorularının incelenmesi. Ana Dili Eğitimi Dergisi, 7(2), 353-367.

\begin{tabular}{c}
$\begin{array}{c}\text { Ana Dili Eğitimi Dergisi } \\
\text { Journal of Mother Tongue Education } \\
\text { www.anadiliegitimi.com }\end{array}$ \\
$\begin{array}{c}\text { Geliş/Received: } 21.02 .2019 \text { Kabul/Accepted } 24.04 .2019 \\
\text { Araştirma Makalesi / Research Paper }\end{array}$ \\
\hline
\end{tabular}

\title{
1.-8. Sınıf Türkçe Ders Kitaplarındaki Metne Dayalı Anlama Sorularının İncelenmesi
}

\author{
Zuhal ÇELIKTÜRK SEZGIN** \\ Yasemin Gül GEDiKOĞLU ÖZILHAN***
}

\section{Öz}

Bu araştırmanın amacı Türkçe ders kitaplarındaki (1.-8. Sınıf) metne dayalı anlama sorularını metin türüne, cevap kaynaklarına ve Barrett taksonomisine dayalı olarak incelemektir. Nitel yaklaşıma dayalı olarak yürütülen çalışmada veriler doküman incelemesine dayalı olarak elde edilmiştir. Araştırmanın çalışma materyallerini Milli Eğitim Bakanlığı tarafından 2018-2019 eğitim-öğretim yılı için hazırlanmış 1.-8. sınıflarda okutulan Türkçe Ders Kitapları oluşturmaktadır. Yapılan incelemenin sonunda 179 metne yönelik 960 anlama sorusu çözümlenmiştir. Verilerin çözümlenmesi süreci araştırmanın alt sorularına dayalı olarak gerçekleştirilmiştir. Araştırmada ilk bulgu olarak, Türkçe ders kitaplarındaki metin türlerinin yaklaşık yarısının öyküleyici türde $(\% 49,7)$, geri kalanların ise bilgilendirici $(\% 28,5)$ ve şiir $(\% 21,7)$ türünde olduğu, bu bulguya paralel olarak da en çok sorunun öyküleyici metin türünde olduğu belirlenmiştir. İkinci olarak, Türkçe ders kitaplarındaki metne dayalı anlama sorularının büyük bir kısmının metin içi anlama sorularından oluştuğu (\%78,3), metin dışı sorulara az yer verildiği $(\% 21,7)$, metinler arası soruların ise hiç sorulmadığı anlaşılmıştır. Üçüncü olarak, metne dayalı anlama sorularının Barrett taksonomisine göre, büyük bir kısmının basit anlama $(\% 66,8)$ düzeyinde olduğu belirlenmiştir. Yeniden organize etme $(\% 10,4)$, çıkarımsal anlama $(\% 8,8)$, değerlendirme $(\% 12,6)$ ve takdir $(\% 1,4)$ türünde sorulara da az oranlarda yer verildiği belirlenmiştir.

Anahtar Kelimeler: Okuduğunu anlama soruları, metin türü, Barrett taksonomisi

\section{Examining Text-Based Comprehension Questions in Turkish Textbooks of the $1^{\text {st }}$ - the $8^{\text {st }}$ Graders}

\begin{abstract}
This study aims to examine text-based comprehension questions in Turkish textbooks $\left(1^{\text {st }}\right.$ to $8^{\text {th }}$ grade) based on text type, sources of response and Barrett's taxonomy. The data of the study which was structured on a qualitative approach were obtained through document review. Materials were composed of Turkish language textbooks prepared by Ministry of National Education to be used in teaching from the $1^{\text {st }}$ to $8^{\text {th }}$ grade in 2018-2019 academic year. 960 text-based comprehension questions of 179 texts were analyzed. The data analysis was carried out in three stages based on the research questions. Findings primarily indicate that approximately half of the text types in Turkish textbooks were narrative $(49.7 \%)$, and the rest were informative $(28.5 \%)$ and poetry $(21.7 \%)$ texts. In line with this finding, it was determined that the most frequent questions were from narrative text type. Secondly, it was found out that most of the text-based comprehension questions in Turkish textbooks consisted of intratextual questions (78.3\%), extratextual questions ranked as the second (21.7\%), and intertextual questions were never asked. Thirdly, it was revealed
\end{abstract}

\footnotetext{
${ }^{* *}$ Dr. Öğr. Üyesi, Burdur Mehmet Akif Ersoy Üniversitesi, Eğitim Fakültesi, Sınıf Eğitimi ABD, Burdur, zuhalcelikturk@gmail.com, ORCID: 0000-0001-7015-8426

${ }^{* * *}$ Dr. Öğr. Üyesi, Burdur Mehmet Akif Ersoy Üniversitesi, Eğitim Fakültesi, Türkçe Eğitimi ABD, Burdur, ygedikoglu@mehmetakif.edu.tr, ORCID: 0000-0003-3293-8995
} 
that while the majority of the text-based comprehension questions were only literal comprehension questions $(66.8 \%)$, very few of them were reorganization $(10,4 \%)$, inferential comprehension $(8,8 \%)$, evaluation $(12,6 \%)$ and appreciation $(1,4 \%)$ questions.

Keywords: Reading comprehension questions, text type, Barrett's taxonomy

\section{Giriş}

Okuma ve beraberinde okuduğunu anlama, ilkokul döneminde edinilmesi gereken temel becerilerdendir. Akyol (2011)'a göre okuma ve okunandan anlam kurma becerisine öğretim programlarında yer verilmesinin nedeni insan hayatına anlam katmaktır. Bu bakış açısıyla bakıldığında okuma ve okunanlardan anlama kurmak, okul hayatı ya da akademik başarı ile sınırlandırılamayacak, insan yaşamının her alanını etkileyecek önemli beceriler olarak görülebilir. Alanyazında okuduğunu anlamanın ortak ve kesin bir tanımı olmamakla birlikte, farklı yaklaşım ve bakış açıklarını barındıran birtakım tanımlar bulunmaktadır. Okuduğunu anlama çeşitli kategoriler ve kavrama becerilerini içeren karmaşık bir entelektüel süreçtir (Dechant, 1981 ve Rubin, 1991; Akt: Lah ve Hashimah, 2014, s. 667). Bu yüzden anlama becerisin kazanılması düşük ve yüksek başarıya sahip öğrenciler için farklı anlamlara gelecektir (Lah ve Hashim, 2014). Rosenblatt (1978)'a göre anlama; okur ile metin arasındaki etkileşime dayanan, öğrenme ve zevk almak amacıyla yapılan bir eylemdir. Duke ve Caslisle (2011) anlamayı sözlü veya yazılı metinle anlama kurma olarak açıklamışlardır. Bu yönüyle okuma yapılandırmacı bir süreçtir. Bir başka tanıma göre de anlama birtakım deneysel olgu ve kuramsal yapı anlamına gelir (Kintsch ve Rawson, 2005). Guthrie (2004) de anlama sürecinde duyuşsal süreçlere dikkat çekmektedir. Yüksek motivasyona sahip bireylerin sıklıkla metni daha iyi anladıklarını işaret etmektedir. Yine Wang ve Guthrie (2004) anlama becerisinin geliştirilmesinde güdüleyici süreçlerin önemli olduğunu belirtmektedir. Kısacası okuduğunu anlama sürecinin kuramsal çerçevesini çizmek oldukça zordur. Çünkü anlama bilişsel, duyuşsal ve fiziksel birtakım unsurları barındırmaktadır.

Okuduğunu anlama ile ilgili bir başka zorlukta anlamanın ölçülüp ve değerlendirilmesinden kaynaklanmaktadır. Bu beceriyi tek başına ölçmek oldukça zor bir süreçtir. Yine herkes tarafından kabul edilmiş, standart bir ölçme aracını geliştirmek ayrı bir zorlu süreçtir. Bu yüzden uzun zamandan bu yana okuduğunu anlamanın ölçülmesi araştırmacıların önemli bir uğraş alanı olmuştur.

Okumada anlam kurmak için kullanılan en önemli araçlardan birisi sorulardır (Akyol, Yıldırım, Ateş ve Çetinkaya, 2013, s. 42). Öğrencilere okudukları hakkında sorular sormak oldukça önemlidir (Fordham, 2006, s.391), sorular metnin kavranmasına yardımcı olur. Akyol, Yıldırım, Ateş ve Çetinkaya (2013)'ya göre iyi hazırlanmış anlama soruları, okuyucun metinle etkileşime girmesine ve anlamı yapılandırmasına yardımcı olur. Guthrie ve Taboada (2004, s. 93) okuma öncesinde ya da okuma sırasında öğrencilere sorulan soruların öğrencilerin metni ya da başlığı anlamasına yardımcı olduğuna değinmektedirler. Bununla ilgili olarak, anlama sürecinde soruların; öğrencinin ön bilgisini harekete geçirmek, öğrencilerde sorunun cevabını bulabilmek için istek oluşturmak ve okumaya olan 


\section{1.-8. Sınıf Türkçe Ders Kitaplarındaki Metne Dayalı Anlama Sorularının İncelenmesi}

motivasyonu sağlamak gibi pek çok işlevi bulunduğunu belirtmektedirler. Hervey (2006)'e göre sorular; cevabı bulmayı araştırmaya ve daha ilerideki sorulara cevap bulabilmek için okumaya olan ilgiyi canlı tutmayı sağladığı için okumanın kalbini oluşturmaktadır. Sorular yoluyla öğrencilerin okuduklarına odaklanmaları, metne derinlemesine bir şekilde girmeleri, anlama açık bir şekilde ulaşmaları ve okudukları hakkında eleştirel düşünmeleri sağlanabilir (Hervey, 2006). Bu yüzden iyi hazırlanmış soruların okuyucuya sorulması okuma öncesi mativasyonunun sağlanması, devamında da metnin anlamlandırılması ve üst düzey düşünme becerilerinin etkinleştirilmesi bakımından oldukça önemlidir. Wixson (1983) okuduklarımızda neden önemsiz olan detayları hatırladığımııı, metnin asıl iletisi olan ana düşünceyi öğrenemediğimizi sorgulamaktadır. Bunun nedeni olarak da, okuduğunu anlamayı değerlendirici sorulara dikkat çekmektedir.

Soruları nasıl bir sistematiğe göre sorabileceğimize ve soruların güçlük düzeyini belirlemede ne tür kategoriler kullanılabileceğine yönelik bazı çalışmalar yapılmıştır. Soruların sınıflandırılmasına ilişkin taksonomilerin kullanımı 1950'lere dayanmaktadır (Bkz. Bloom, 1956). Anlamada taksonominin kullanımı, sorulacak soruların belli bir sisteme dayalı olarak farklı türde sorulmasına duyulan ihtiyaçtan ortaya çıkmıştır. Alanyazın tarandığında çeşitli kategoriler veya taksonomiler olduğu görülmüştür (Akyol, 1996; Bloom, 1956, Barrett, 1968; Day ve Park, 2005; Hyman, 1979; Nicholas ve Tarabasso, 1979; Pearson ve Johnson, 1978; Sanders, 1966; Wallen, 1972). Bu taksonomilere genel olarak bakıldığında, iki ile altı seviye arasında değişen kategorilerden oluştuğu söylenebilir.

Pearson ve Johnson (1978) okuyucunun cevap kaynağına göre soruyu cevaplamada kullanabilecekleri sınıflamadan söz etmektedir. Bu sınıflamaya göre sorular üç türde sınıflanabilir. Birincisi, sorunun cevabı doğrudan metin içinde bulunabilen "metinsel olarak açık sorular", ikincisi metin içinde cevabın doğrudan verilmesi yerine örtük bir şekilde cevabı bulunan "metinsel olarak örtük sorular", üçüncü olarak da, cevabı metin içinde olmayan okuyucunun ön bilgilerine dayalı olan "kodsal olarak örtük sorular"dır. Benzer bir sınıflama Akyol (1996) tarafından yapılmıştır. Akyol'a göre metinlerden anlam kurmak için sorulan sorular metin içi, metin dışı ve metinler arası olarak sınıflanabilir.

Barrett taksonomisi (1968), özellikle okuma alanında öğrencilerin anlama becerilerini ölçmek üzere geliştirilmiştir. Taksonomi ilk olarak, öğretmenler tarafından sınıf içinde anlama sorularının sınıflandırmasında ve hazırlanmasında kullanılmıştır (Clymer, 1968). Barrett (1968) daha önceki çalışmalardan yararlanarak "Bilişsel ve Duyuşsal Boyutlar" taksonomisini tasarlanmıştır. Barrett geliştirdiği taksonomiyi beş basamakta ele almıştır: basit anlama, yeniden organize etme, çıkarımsal anlama, değerlendirme ve takdir. Öğretimsel amaçlar bağlamında her kategori için özel beceri hedefleri oluşturmuştur (Ruddell, 1978, s.8). 
Gerek ulusal gerekse uluslararası alanyazında okuduğunu anlamayı değerlendirmede kullanılan soruların incelenmesi üzerine pek çok araştırmanın varlığından söz edilebilir (Aktaş, 2017; Akyol, 1997, 2001; Akyol, Yıldırım, Ateş ve Çetinkaya, 2013; Applegate, 2007; Aslan, 2011; Ateş, Güray, Döğmeci ve Gürsoy, 2016; Bozkurt, Uzun ve Lee, 2015; Day ve Park, 2005; Durukan, 2009; Göçer, 2014; Güfta ve Zorbaz, 2008; Kocaarslan ve Yamaç, 2018; Klingner, 2004; Kuzu, 2013; Parker ve Hurry, 2007; Savaşkan, 2016; Ülper ve Yalınkılıç, 2010; Yıldırım, 2012). Yurt içinde yapılan okuduğunu anlama sorularının sınıflamasına yönelik çalışmalara bakıldığında, daha çok Bloom Taksonomisine dayalı (Aktaş, 2017; Aydemir ve Çiftçi, 2008; Çeçen ve Kurnaz, 2015; Güfta ve Zorbaz, 2010; Keray ve Güden, 2013; Kuzu, 2013) olduğu görülmüştür. Barrett taksonomisine dayalı olarak soruların sınıflamalarını inceleyen taksonomilere ilişkin çalışmalar da bulunmaktadır (Akyol, Yıldırım, Ateş ve Çetinkaya; 2013; Ateş, Güray, Döğmeci ve Gürsoy, 2016; Çelik, Demirgüneş ve Fidan, 2015; Göçer, 2014; Yıldırım, 2012;). Ancak alanyazında Türkçe ders kitaplarındaki metne dayalı anlama sorularını Barrett Taksonomisine göre inceleyen bir araştırmaya rastlanılmamıştır. Bu taksonomiye dayalı olarak Türkçe ders kitaplarındaki metin sorularının incelenmesi ve değerlendirilmesi; mevcut ders kitaplarındaki soruların niteliği hakkında bilgi vereceği ve bundan sonra hazırlanacak kitaplardaki sorulara ilişkin öneriler getireceği düşünülmektedir. Bu bağlamda, araştırmanın amacı 1.-8. sınıflar Türkçe ders kitaplarındaki metne dayalı anlama sorularını incelemektir. Bu amaç doğrultusunda çalışmada şu sorulara yanıt aranmıştır.

1. Türkçe ders kitaplarındaki metne dayalı anlama sorularının metin türüne göre dağıımı nasıldır?

2. Türkçe ders kitaplarındaki (1.-8. Sınıf) metne dayalı anlama sorularının cevap kaynaklarına göre dağılımı nasıldır?

3. Türkçe ders kitaplarındaki (1.-8. Sınıf) metne dayalı anlama sorularının Barrett Taksonomisine göre dağılımı nasıldır?

\section{Yöntem}

\section{Araştırmanın Modeli}

Araştırma nitel araştırma yaklaşımına uygun bir şekilde yürütülmüştür. Bu çerçevede araştırmanın verileri doküman incelemesi ile toplanmıştır. Doküman incelemesi, araştırılması planlanan konu ya da olaylara ilişkin bilgileri içeren yazılı materyallerin analizine yönelik bir veri toplama yöntemidir (Yıldırım ve Şimsek, 2008, s. 187).

\section{Veriler ve Toplanması}

Çalışmanın verilerini, 1.,2.,3.,4.,5.,6.,7. ve 8. sınıflarda okutulan Türkçe Ders Kitapları oluşturmaktadır. Bu kapsamda 2018-2019 eğitim-öğretim yılı için hazırlanmış farklı yayınevlerinin 


\section{1.-8. Sınıf Türkçe Ders Kitaplarındaki Metne Dayalı Anlama Sorularının İncelenmesi}

Türkçe ders kitapları arasında tarama yapılmıştır. Bu kapsamda birinci, üçüncü, dördüncü, beşinci, altıncı, yedinci ve sekizinci sınıf Türkçe ders kitabında Milli Eğitim Bakanlığı yayınları, ikinci sınıf Türkçe ders kitabında Koza yayınlarının kitapları araştırmada incelenmek üzere seçilmiştir. İkinci sınıf Türkçe ders kitabında farklı bir yayınevinin seçilme nedeni, Milli Eğitim Bakanlığı yayınına ulaşılamamış olmasıdır.

\section{Verilerin Çözümlenmesi}

Doküman analizi için toplanan Türkçe ders kitaplarındaki metinler sınıf seviyelerine ve belirli kategorilere dayalı olarak incelenmiştir. Verilerin çözümlenmesinde içerik çözümlemesi tekniğinden yararlanılmıştır. İlk olarak, kitaplardaki metne dayalı anlama sorularının tamamı bilgisayar ortamında çalışma aktarıımıştır. Daha sonra sorular metin türlerine göre, cevap kaynaklarına göre, Barrett Taksonomisi (1968)'ne göre sınıflandırılmıştır. Yapılan sınıflamanın ardından, veriler frekans ve yüzde olarak incelenmiştir. Taksonomi; basit anlama, yeniden organize etme, çıkarımsal anlama, değerlendirme ve takdir olmak üzere beş kategoriden oluşmaktadır (Bkz. Tablo 1). İlk iki kategori (basit anlama ve yeniden organize etme) öğrencilerin okuduklarından hareketle cevaplayabilecekleri soruları kapsamaktadır. Bu sorular, tek bir cevabı olan ve kapalı uçlu sorulardır. Diğer üç kategori (çıkarımsal anlama, değerlendirme ve takdir) ise öğrencinin kendi deneyimlerini içeren açık uçlu sorulardan oluşmaktadır. Öğrencinin, geçmiş yaşam deneyimlerine bağlı olarak cevabı farklılaşabilen sorulardır (Yıldırım, 2012). Bahsi geçen taksonomiye ilişkin kategoriler ve görevler Tablo 1'de yer almaktadır.

Araştırma kapsamında, sekiz ders kitabındaki 179 metne yönelik 960 anlama sorusu incelenmiştir.

Tablo 1. Barrett Taksonomisi

\begin{tabular}{|c|c|}
\hline $\begin{array}{l}\text { Ana } \\
\text { kategoriler }\end{array}$ & Açıklamalar ve görevler \\
\hline 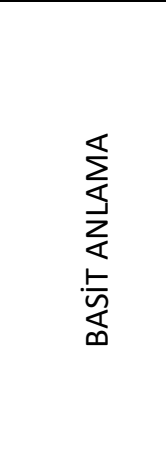 & $\begin{array}{l}\text { Metinde cevabı açıkça belirtilmiş olan fikir ve bilgilere odaklanır. Okuyucundan beklenen, tek } \\
\text { bir olgu veya olayın tanınması veya hatırlanmasıdır. Ya da daha karmaşık görevlerde bir olgu } \\
\text { ya da olayın tanınması, hatırlanması veya sıralanması olabilir. Bu basamakta sorulan soruların } \\
\text { güçlük düzeyi okuma amaçları ve öğretmenin amaçları doğrultusunda değişebilir. Basit } \\
\text { anlamanın görevleri şunlardır: } \\
\text { - Detayları fark etme ve hatırlama } \\
\text { - Anafikri fark etme ve hatırlama } \\
\text { - Sırasını fark etme ve hatırlama } \\
\text { - Neden ve sonuç ilişkilerini fark etme ve hatırlama } \\
\text { - Karşılaştırmaları fark etme } \\
\text { - Karakter davranışlarını fark etme ve hatırlama }\end{array}$ \\
\hline
\end{tabular}




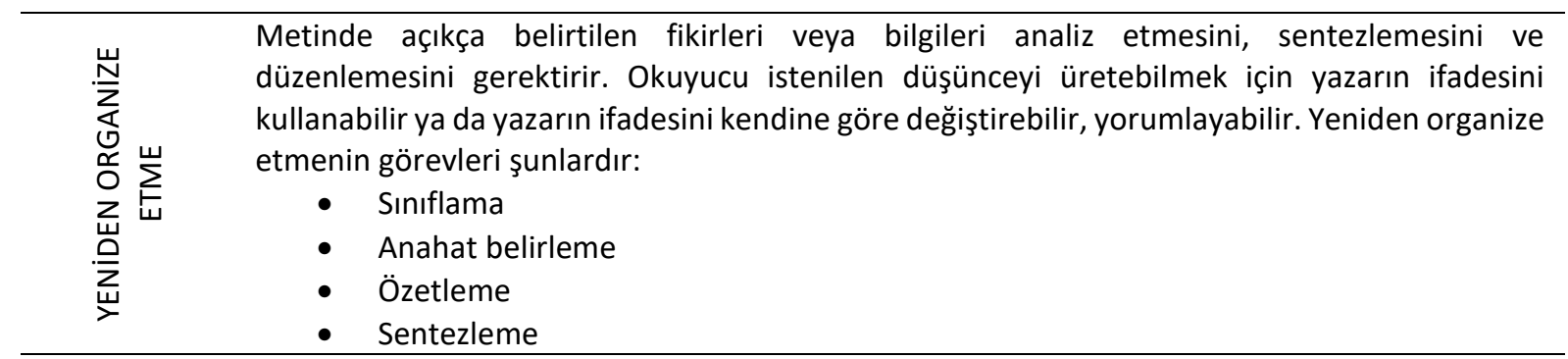

Metindeki bilgilerden hareketle, okuyucunun kendi fikirlerini, sezgilerini ve kişisel deneyimlerini kullanmasını gerektirir. Çıkarımsal anlama; basıı sayfanın ötesine geçen düşünce ve hayal gücü gerektiren soruları kapsamaktadır. Öğrencilerin yaptığı çıkarımlar $\varangle \quad$ birbirinden farklı olabilir, öğrencilerin çıkarımlarının altında yatan nedenler araştırılabilir. Kişisel deneyimlerin yanında okulda öğrenilen bilgilerin de yorumlanmasıdır. Çıkarımsal anlamanın görevleri şunlardır:

- Destekleyici detayları çıkarma

- Anafikri çıkarma

- Sırasını çıkarma

- Karşılaştırmaları çıkarma

- Neden ve sonuç ilişkilerini çıkarma

- Karakter davranışlarını çıkarma

- Sonucu tahmin etme

- Mecazi dili çıkarma

Metinde verilen fikirleri; öğretmen ve diğer kaynaklar tarafından sağlanan dış ölçütlerle ya da okuyucunun deneyimleri, bilgileri ve değerleri gibi iç ölçütlerle karşılaştırarak $\sum_{\Omega}^{\omega} \quad$ değerlendirmesidir. Değerlendirmenin özünde yargı, doğruluk ve kabul edilebilirlik, arzu edilebilirlik ve olma olasılı̆̆ı vardır. Değerlendirmenin görevleri şunlardır:

- Hayali veya gerçeği değerlendirme

- Gerçekleri veya fikirleri değerlendirme

- Yeterliğini ve geçerliğini değerlendirme

- Uygunluğunu değerlendirme

- Değer, arzu ve kabul edilebilirliğini değerlendirme

Okuyucunun duygusal ve estetik tepkisini ele aldığı için okumanın bütün bilişsel boyutlarını kapsamaktadır. Okuyucuda duygusal ve estetik değerlere çağrışımda bulunduğu için sanatsal unsurları ele alır. Bu yüzden; edebi tekniklere, biçim ve üsluba ilişkin hem bilgi hem de duygusal tepkiyi içerir. Takdirin görevleri şunlardır:

- Iç̧eriğe duygusal tepki

- Karakterlere veya olaylara tepki

- Yazarın dil kullanımına tepki

- Imgeleme

Kaynak: Barrett Taksonomisi Dokümanından uyarlanmıştır. ${ }^{1}$

Araştırmanın güvenirliği için Türkçe Ders kitaplarından (1-8. Sınıf) elde edilen veriler, araştırmanın her araştırma sorusu için iki araştırmacı tarafından ayrı ayrı değerlendirilmiştir. Değerlendirme yapılmadan önce, ders kitaplarındaki metne dayalı anlama soruları tek tek yazılmıştır ve bu sorulara uygun olarak veriler sınıflandırılmıştır. Değerlendiriciler arasındaki uyum katsayısını belirlemek için Krippendorff Alfa katsayısı ( $\alpha$ ) ile hesaplama yapışmıştır. Bu katsayı puanlayııılar arasındaki uyumu belirlemek amacıyla kullanılmaktadır (Krippendorff, 1995). Yapılan istatistiksel hesaplama sonucu puanlayıcılar arasındaki uyum değerinin yani Krippendorff Alfa katsayısının $(\alpha) .77$ ile .92 arasında değiştiği görülmüştür. $\alpha$ değerinin .67 'den küçük olması zayıf , .67 ile .80 arasında ise orta, .80 ve üzeri ise yüksek olduğunu göstermektedir (Krippendorff, 1995). Bu değer aralıklarına göre 


\section{1.-8. Sınıf Türkçe Ders Kitaplarındaki Metne Dayalı Anlama Sorularının Incelenmesi}

bakıldığında değerlendiriciler arasında uyumun orta ve yüksek düzeyde olduğu söylenebilir. Yapılan analiz sonrasında iki kodlayıcı, kodlama sonuçlarını karşılaştırmış ve fikir ayrılığı yaşanan sorular yeniden gözden geçirilmiş ve fikirbirliği sağlanmaya çalışılmıştır.

Araştırmadaki metne dayalı anlama sorularının bazılarının iki aşamadan oluştuğu görülmüştür. Örneğin, yedinci sınıf Türkçe ders kitabında "Yazara göre "kendimizle barışık olduğumuzun göstergesi" nedir? Siz, kendinizle barışık olduğunuzu düşünüyor musunuz?" gibi sorular için, cevap kaynağına göre (metin içi-metin dışı), Barrett Taksonomisine göre (basit anlama-değerlendirme) gibi ikili kodlama yapılmıştır. Bu yüzden araştırmadaki toplam soru sayısı Tablo 2, 3 ve 4'te farklılık göstermektedir.

\section{Bulgular}

Araştırmada toplam 179 metin ve bu metinlere dayalı 960 tane soru tespit edilmiştir. Araştırmanın alt sorularına dayalı olarak bulgular verilmiştir.

Araştırmanın Birinci Alt Sorusuna ilişskin Bulgular

Türkçe ders kitaplarındaki (1.-8. Sınıf) metinlerin türüne göre dağılımı Tablo 2'de yer almaktadır.

Tablo 2. Türkçe Ders Kitaplarındaki Metne Dayalı Anlama Sorularının Metin Türüne Göre Dağılımı

\begin{tabular}{lcccccccc}
\hline & \multicolumn{2}{c}{ Bilgilendirici } & \multicolumn{2}{c}{ Öyküleyici } & \multicolumn{2}{c}{ Şiir } & \multicolumn{2}{c}{ Toplam } \\
& $f$ & $\%$ & $f$ & $\%$ & $f$ & $\%$ & $f$ & $\%$ \\
\hline TOPLAM METiN SAYISI (1.-8. & 51 & 28,5 & 89 & 49,7 & 39 & 21,8 & 179 & 100 \\
SINIF) & & & & & & & & \\
\hline CEVAP KAYNAĞINA GÖRE & & & & & & & & \\
SORULAR (1.-8. SINIF) & 213 & 32,2 & 311 & 47,0 & 138 & 20,8 & 662 & 100 \\
$\quad$ Metin İçi & 54 & 24,3 & 118 & 53,2 & 50 & 22,5 & 222 & 100 \\
$\quad$ Metin DIşı & 0 & 0 & 0 & 0 & 0 & 0 & 0 & 0 \\
$\quad$ Metinler Arası & 267 & 30,2 & 429 & 48,5 & 188 & 21,3 & 884 & 100 \\
$\quad$ TOPLAM & & & & & & & & \\
\hline BARRETT TAKSONOMiSiNE GÖRE & & & & & & & & \\
SORULAR (1.-8. SINIF) & 192 & 26,4 & 349 & 47,9 & 187 & 25,7 & 728 & 100 \\
$\quad$ Basit Anlama & 23 & 22,8 & 47 & 46,5 & 31 & 30,7 & 101 & 100 \\
$\quad$ Yeniden Organize Etme & 19 & 22,3 & 45 & 53,0 & 21 & 24,7 & 85 & 100 \\
$\quad$ Çıkarımsal Anlama & 29 & 23,7 & 65 & 53,3 & 28 & 23,0 & 122 & 100 \\
$\quad$ Değerlendirme & 2 & 15,4 & 9 & 69,2 & 2 & 15,4 & 13 & 100 \\
$\quad$ Takdir & 265 & 25,3 & 515 & 49,1 & 269 & 25,6 & 1049 & 100 \\
$\quad$ TOPLAM & & & & & & & &
\end{tabular}

Tabloda görüldüğü üzere, Türkçe ders kitaplarındaki (1.-8. sınıf) metin türlerinin yaklaşık yarısının öyküleyici türde $(\% 49,7)$, geri kalanların ise bilgilendirici $(\% 28,5)$ ve şiir $(\% 21,8)$ türünde olduğu belirlenmiştir. Tablodan anlaşıldığı üzere, metin türlerinin dağılımı eşit orana sahip değildir. Yine Türkçe ders kitaplarındaki (1.-8.) soruların metin türlerine göre dağılımına bakıldığında en çok soru sayısının öyküleyici metin türünde olduğu görülmüştür. Türkçe ders kitaplarındaki metne dayalı anlama sorularının cevap kaynağına göre dağılımına bakıldığında üç metin türünde de en çok metin içi sorular 
sorulmuştur. Barrett taksonomisine göre soruların dağııımına bakıldığında, üç metin türünde de (bilgilendirici, öyküleyici, şiir) en çok basit anlama basamağında soru sorulduğu tespit edilmiştir.

\section{Araştırmanın Ikinci Alt Sorusuna ilişskin Bulgular}

Türkçe ders kitaplarındaki (1.-8. sınıf) metne dayalı anlama sorularının cevap kaynaklarına göre dağılımı Tablo 3'te yer almaktadır.

Tablo 3. Türkçe Ders Kitaplarındaki Metne Dayalı Anlama Sorularının Cevap Kaynaklarına Göre Dağılımı

\begin{tabular}{lcccccccc}
\hline \multirow{2}{*}{ SINIF SEViYELERi } & \multicolumn{2}{c}{ Metnin İçi } & \multicolumn{2}{c}{ Metin Dışı } & \multicolumn{2}{c}{ Metinler arası } & \multicolumn{2}{c}{ Toplam } \\
& $f$ & $\%$ & $f$ & $\%$ & $f$ & $\%$ & $f$ & $\%$ \\
\hline Birinci Sınıf Türkçe Ders Kitabı & 55 & 98,2 & 1 & 1,8 & 0 & 0 & 56 & 100 \\
İkinci Sınıf Türkçe Ders Kitabı & 106 & 99,0 & 1 & 1,0 & 0 & 0 & 107 & 100 \\
Üçüncü Sınıf Türkçe Ders Kitabı & 127 & 98,4 & 2 & 1,6 & 0 & 0 & 129 & 100 \\
Dördüncü Sınıf Türkçe Ders Kitabı & 141 & 94,6 & 8 & 5,4 & 0 & 0 & 149 & 100 \\
Beşinci Sınıf Türkçe Ders Kitabı & 94 & 67,6 & 45 & 32,4 & 0 & 0 & 139 & 100 \\
& 75 & 61,0 & 48 & 39,0 & 0 & 0 & 123 & 100 \\
Altıncı Sınıf Türkçe Ders Kitabı & 72 & 50,0 & 72 & 50,0 & 0 & 0 & 144 & 100 \\
Yedinci Sınıf Türkçe Ders Kitabı & 83 & 64,8 & 45 & 35,2 & 0 & 0 & 128 & 100 \\
Sekizinci Sınıf Türkçe Ders Kitabı & 800 & 78,3 & 222 & 21,7 & 0 & 0 & 1022 & 100 \\
TOPLAM & & & & & & & 0 \\
\hline
\end{tabular}

Tabloda görüldüğü üzere, Türkçe ders kitaplarındaki (1.-8. sınıf) metne dayalı anlama sorularının büyük bir kısmı metin içi $(\% 78,3)$ anlama sorularından oluştuğu, metin dışı sorulara ise az yer verildiği anlaşılmaktadır (\%21,7). Araştırma kapsamında incelenen tüm sorularda metinler arası türünde soru belirlenmemiştir. Sınıflara göre karşılaştırma yapıldığında ise, metin içi soruların oranında birinci sınıftan üst sınıflara doğru gidildikçe azalma olduğu, metin dışı soruların oranında da artış olduğu belirlenmiştir.

\section{Araştırmanın Üçüncü Alt Sorusuna iliş̧kin Bulgular}

Türkçe ders kitaplarındaki (1.-8. Sınıf) metne dayalı anlama sorularının Barrett Taksonomisine göre dağılımı Tablo 4'te yer almaktadır.

Tablo 4. Türkçe Ders Kitaplarındaki Metne Dayalı Anlama Sorularının Barrett Taksonomisine Göre Dağılımı

\begin{tabular}{|c|c|c|c|c|c|c|c|c|c|c|c|c|}
\hline \multirow[t]{2}{*}{ SINIF SEVIYELERI } & \multicolumn{2}{|c|}{ Basit Anlama } & \multicolumn{2}{|c|}{$\begin{array}{c}\text { Yeniden } \\
\text { Organize } \\
\text { Etme }\end{array}$} & \multicolumn{2}{|c|}{$\begin{array}{l}\text { Çıkarımsal } \\
\text { Anlama }\end{array}$} & \multicolumn{2}{|c|}{ Değerlendirme } & \multicolumn{2}{|c|}{ Takdir } & \multicolumn{2}{|c|}{ Toplam } \\
\hline & $f$ & $\%$ & $f$ & $\%$ & $f$ & $\%$ & $f$ & $\%$ & $f$ & $\%$ & $f$ & $\%$ \\
\hline $\begin{array}{l}\text { Birinci Sınıf } \\
\text { Türkçe Ders Kitabı }\end{array}$ & 47 & 83,9 & 9 & 16,1 & 0 & 0 & 0 & 0 & 0 & 0 & 56 & 100 \\
\hline $\begin{array}{l}\text { İkinci Sınıf Türkçe } \\
\text { Ders Kitabı }\end{array}$ & 98 & 91,6 & 9 & 8,4 & 0 & 0 & 0 & 0 & 0 & 0 & 107 & 100 \\
\hline $\begin{array}{l}\text { Üçüncü Sınıf } \\
\text { Türkçe Ders Kitabı }\end{array}$ & 118 & 91,5 & 10 & 7,7 & 1 & 0,8 & 0 & 0 & 0 & 0 & 129 & 100 \\
\hline $\begin{array}{l}\text { Dördüncü Sınıf } \\
\text { Türkçe Ders Kitabı }\end{array}$ & 126 & 85,1 & 16 & 10,8 & 6 & 4,1 & 0 & 0 & 0 & 0 & 148 & 100 \\
\hline
\end{tabular}


1.-8. Sınıf Türkçe Ders Kitaplarındaki Metne Dayalı Anlama Sorularının İncelenmesi

\begin{tabular}{|c|c|c|c|c|c|c|c|c|c|c|c|c|}
\hline $\begin{array}{l}\text { Beşinci Sınıf } \\
\text { Türkçe Ders Kitabı }\end{array}$ & 66 & 48,2 & 20 & 14,5 & 32 & 23,4 & 16 & 11,7 & 3 & 2,2 & 137 & 100 \\
\hline $\begin{array}{l}\text { Altıncı Sınıf } \\
\text { Türkçe Ders Kitabı }\end{array}$ & 67 & 54,9 & 12 & 9,8 & 11 & 9,1 & 28 & 22,9 & 4 & 3,3 & 122 & 100 \\
\hline $\begin{array}{l}\text { Yedinci Sınıf } \\
\text { Türkçe Ders Kitabı }\end{array}$ & 68 & 47,2 & 8 & 5,6 & 17 & 11,8 & 50 & 34,7 & 1 & 0,7 & 144 & 100 \\
\hline $\begin{array}{l}\text { Sekizinci Sınıf } \\
\text { Türkçe Ders Kitabı }\end{array}$ & 57 & 45,6 & 17 & 13,6 & 18 & 14,4 & 28 & 22,4 & 5 & 4,0 & 125 & 100 \\
\hline TOPLAM & 647 & 66,8 & 101 & 10,4 & 85 & 8,8 & 122 & 12,6 & 13 & 1,4 & 968 & 100 \\
\hline
\end{tabular}

Tabloda görüldüğü üzere, Türkçe ders kitaplarındaki (1.-8. sınıf) metne dayalı anlama sorularının büyük bir kısmının basit anlama $(\% 66,8)$ düzeyinde olduğu anlaşımaktadır. Yeniden organize etme $(\% 10,4)$, çıkarımsal anlama $(\% 8,8)$, değerlendirme $(\% 12,6)$ ve takdir $(\% 1,4)$ türünde sorulara da yer verildiği belirlenmiştir. Sınıflara göre karşılaştırma yapıldığında ise, değerlendirme ve takdir türünde soruların beşinci sınıftan sonra sorulduğu anlaşılmıştır. Bir başka ifadeyle, ilkokulda bu basamaklarda hiç soru sorulmadığı belirlenmiştir. Sınıflara göre soru türlerinin dağılımına bakıldığında, her sınıf seviyesinde basit anlama sorularının çokluğu dikkat çekmektedir (\%45,6 ile \%91,6 arasında değişmektedir). Araştırmanın bir başka bulgusu da öğrencilerin doğrudan metin içinde cevabını bulabileceği ya da yazarın ifadelerini yeniden düzenleyerek cevap verebileceği soru türü olan basit anlama ve yeniden organize etme türünde sorular, tüm sınıflarda en çok sorulan sorulardır. Birinci ve ikinci sınıftaki soruların tamamı, üçüncü ve dördüncü sınıftaki soruların büyük çoğunluğu basit anlama ve yeniden organize etme türünde sorulardan oluşmaktadır (üçüncü sınıf \%99,2; dördüncü sınıf \%95,9). Beşinci, altıncı, yedinci ve sekizince sınıfta da soruların çoğunluğu basit anlama ve yeniden organize etme türündedir (beşinci sınıf \%62,7; altıncı sınıf \%64,7; yedinci sınıf \%52,8; sekizinci sınıf \%59,2).

\section{Sonuç, Tartışma ve Öneriler}

Bu araştırmada, Türkçe ders kitaplarındaki metne dayalı anlama soruları çeşitli yönlerden incelenmiştir. Yapılan incelemenin sonunda, Türkçe ders kitaplarındaki (1.-8. Sınıf) metin türlerinin yaklaşık yarııının öyküleyici türde, geri kalanların ise bilgilendirici ve şiir türünde olduğu belirlenmiştir. Milli Eğitim Bakanlığı (2018), Türkçe Dersi Öğretim Programında metin türleri ile ilgili şu ifadelere yer vermiştir:

\footnotetext{
"Metin türleri 3 ana biçim altında toplanmıştır: Bilgilendirici, hikâye edici, şiir. Belirtilen metin sayıları içinde kalmak kaydıyla hangi temada, hangi metin türlerinin yer alacağı ders kitabı yazarının/yazarlarının tercihine bağlıdır. Metin türlerinin dengeli dağılıp dağılmadığı metin biçimlerine göre belirlenecektir. Örneğin "Bilim ve Teknoloji" temasında bilgilendirici metin daha fazla olabilir. Başka bir temada ise şiir türündeki metinlere daha fazla yer verilebilir. Ancak ilke olarak metin türlerinin temalar arasında, kitap bütününde dengeli bir şekilde dağıımının sağlanması esastır."
}

Yukarıdaki açıklamadan da anlaşıldığı üzere, Türkçe ders kitaplarındaki metin türlerinin dengeli bir biçimde dağılması vurgusu yapılmıştır. Ancak araştırmanın sonunda; Türkçe ders kitaplarındaki 
metin türlerinin anlamlı bir dağııım göstermediği, tüm sınıflarda öyküleyici türde metinlerin çoğunlukta olduğu belirlenmiştir. Öğretici ve yazınsal türde metinler çocukların farklı beceri alanlarını devindirmesine olanak sağlamaktadır. Öğretici metinler, çocuklarda düşünce oluşturma ve yansıtma gücünü desteklemektedir. Yazınsal metinler ise; dilin imge oluşturma, ilişkilendirme ve dönüştürme gibi özelliklerini çocuklara hissettirmektedir. Türkçe öğretiminde kullanılan yazınsal metinler aracılığıyla çocuklar duyumsatılan iletileri alımlayabilmek, metnin anlamının oluşmasına katkı sağlayabilmek için duygu ve düşünce üretme gereksinimi duymalıdırlar. Bu üretim, çocuğun kavramsal gelişimine, yaşama ve insana ilişkin duyarlık kazanmasına katkı sağlar (Sever, 2008). Bu açıdan bakıldığında farklı metin türlerine yer vermek farklı beceri alanlarına katkı sağlayacağı için oldukça önemli görülmektedir.

Araştırmanın bir başka bulgusu, Türkçe ders kitaplarındaki metne dayalı anlama sorularının üç metin türünde de en çok metin içi soruların sorulmasıdır. Barrett taksonomisine göre soruların, üç metin türünde de (bilgilendirici, öyküleyici, şiir) en çok basit anlama basamağında soru sorulduğu tespit edilmiştir.

Araştırmada, Türkçe ders kitaplarındaki (1.-8. sınıf) metne dayalı anlama sorularının büyük bir kısmı metin içi anlama sorularından oluştuğu, metin dışı sorulara ise az yer verildiği belirlenmiştir. Metinler arası türünde soru ise belirlenmemiştir. Akyol (2001) beşinci sınıf Türkçe kitaplarındaki okuma metinleriyle ilgili soruları inceleyen araştırmasında metin sonrası soruların yaklaşık \%97'sinin metin içi sorulardan oluştuğunu tespit etmiştir. Yine Akyol vd.'nin (2013) sınıf öğretmeni adaylarının ürettikleri soruları inceleyen araştırmalarında öğretmenlerin cevabı metin içerisinde olan soruları sorma eğiliminde oldukları belirlenmiştir. Bu araştırmadan elde edilen sonuçların, diğer araştırma sonuçları ile benzerlik gösterdiği anlaşılmaktadır.

Barrett taksonomisine göre, Türkçe ders kitaplarındaki (1.-8. Sınıf) metne dayalı anlama sorularının büyük bir kısmının basit anlama düzeyinde olduğu belirlenmiştir. Yeniden organize etme, çıkarımsal anlama, değerlendirme ve takdir türünde sorulara ise daha az yer verilmiştir. Yani üst düzey düşünme becerisi gerektiren sorulara az yer verildiği belirlenmiştir. Yine, değerlendirme ve takdir türünde soruların beşinci sınıftan sonra sorulduğu, ilkokulda bu basamakta hiç soru sorulmadığı anlaşılmıştır. Sınıflara göre soru türlerinin dağıımına bakıldığında, her sınıf seviyesinde basit anlama sorularının çokluğu dikkat çekmektedir. Oysa okumanın özü, okuyucunun geçmiş deneyimleri ile metni bağlayabilmektir. Okuyucunun, metindeki bilgilerden veya karakterlerden hareketle tahmin etmesine olanak sağlayan birtakım sorular üst düzey düşünme ölçütlerini sağlayacaktır (Applegate, Quinn ve Applegate, 2002). 


\section{1.-8. Sınıf Türkçe Ders Kitaplarındaki Metne Dayalı Anlama Sorularının İncelenmesi}

$\mathrm{Bu}$ araştırmadan elde edilen bulguların, Türkçe dersinde sorulan anlama soruların sınıflandırılmasına ve değerlendirilmesine yönelik yapılan çeşitli araştırmadan elde edilen bulgularla örtüştüğü görülmüştür. Durukan (2009)'ın yedinci sınıf Türkçe ders kitaplarındaki metne dayalı anlama sorularını inceleyen araştırmasında, soruların yoğunlukla bilgi ve kavrama düzeyinde olduğunu belirlemiştir. Yine Akyol, Yıldırım, Ateş ve Çetinkaya (2013) çalışmalarında Türkçe dersinde öğretmenlerin sıklıkla basit anlama düzeyine yönelik soru sormaya eğilimli olduklarını ve ürettikleri soruların öğrencilerin üst düzey düşünme becerilerini geliştirmeye yönelik olmadığı sonuçlarına varılmışlardır. Ateş, Güray, Döğmeci ve Gürsoy (2016) araştırmalarında, öğretmenlerin sordukları soruların Barrett taksonomisine göre $\% 76^{\prime}$ sının basit anlama, $\% 8^{\prime}$ inin yeniden organize etme ve \%10'unun çıkarım düzeyinde, az sayıda da değerlendirme ve memnuniyet düzeyinde olduğunu belirlemişlerdir. Güfta ve Zorbaz (2008) ortaokulda Türkçe dersindeki yazılı sınav sorularını ve Kocaarslan ve Yamaç (2018) da sınıf öğretmenlerinin Türkçe dersindeki sınav sorularını inceleyen araştırmalarında; anlama sorularının alt düzey becerileri ölçen basit anlama sorularından oluştuğunu belirlemişlerdir. Çeçen ve Kurnaz (2015) farklı yayınevlerinin ortaokul Türkçe ders kitaplarındaki tema sonu değerlendirme sorularını inceleyen araştırmalarında Bloom taksonomisine soruların yarısından fazlasının anlama basamağında olduğunu saptamışlardır. Kutlu (1999)'nun 1.-8. sınıf Türkçe ders kitaplarında yer alan soruları inceleyen araştırmasında, soruların en çok hatırlama düzeyinde olduğu, üst düzey bilişsel beceri gerektiren soruların sorulmadığı bulgusuna varmıştır. Yine Aydemir ve Çiftçi (2008)'in edebiyat öğretmeni adaylarının soru sorma becerilerini inceleyen araştırmalarında, öğretmen adaylarının sordukları soruların Bloom taksonomisine göre yarısından fazlasının bilgi ve kavrama basamağında olduğu sonucuna ulaşılmıştır. Eroğlu ve Sarar Kuzu (2014)'nun Türkçe ders kitaplarındaki dilbilgisi sorularını inceleyen araştırmalarında soruların yaklaşık \%60'ının hatırlama ve anlama basamağında olduğu belirlenmiştir. Kuzu (2013), Türkçe ders kitaplarındaki metin altı soruları inceleyen araştırmasında soruların Bloom taksonomisine göre \%36'sının hatırlama, \%39'unun anlama düzeyinde olduğunu tespit etmiştir. Ülper ve Yalınkılıç (2010) farklı öğrenme kuramlarına göre hazırlanmış (davranış̧̧ı ve yapılandırmacı) Türkçe ders kitaplarındaki metin sonu soruları karşılaştıran araştırmalarında, yapılandırmacı yaklaşıma göre hazırlanan Türkçe ders kitabındaki soruların, davranış̧ı yaklaşıma göre hazırlanan Türkçe ders kitabına göre daha çok üst düzey bilişsel işlemleme gerektiren sorulara yer verdiği görülmüştür. Aslan (2011), Türk dili ve edebiyatı bölümü öğrencilerinin soru sorma becerilerini geliştirmeye yönelik araştırmasında, katııımcıların çalışmanın öncesinde çoğunlukla düşük düzeyli sorular ürettiklerini belirlemiş̧ir. Bozkurt, Uzun ve Lee (2015), Korece ve Türkçe ders kitaplarındaki metin sonu sorularını karşılaştıran araştırmalarında bilgiye ulaşma ve hatırlama düzeyindeki soruların Korece ders kitabı örnekleminde oranının \%36, Türkçe ders kitabı örnekleminde oranının \%50 olduğunu belirlemiştir. Aktaş (2017) öğretmen adaylarının farklı metin 
türlerine göre soru sorma becerilerini değerlendirilmesini amaçlayan araştırmada, öğretmen adaylarının üst düzey düşünme becerilerini geliştirici sorular sormakta yetersiz oldukları belirlenmiştir.

Bu araştırma, 2018-2019 eğitim öğretim yılı için hazırlanmış belli yayınevlerinin Türkçe ders kitaplarındaki (1.-8. sınıf) metne dayalı anlama soruları ile sınırlıdır, gelecekteki araştırmalarda Türkçe ders kitaplarının yayınevlerinin sayısı artırılabilir.

Araştırmada, Türkçe ders kitaplarındaki metne dayalı anlama soruları metin türlerine, cevap kaynaklarına ve Barrett taksonomisine göre sınıflandııımıştır. Ileride yapılacak araştırmalarda benzer bir çalışmanın farklı bir taksonomi ile gerçekleştirilmesi önerilmektedir.

Okullarda, Türkçe dersi Milli Eğitim Bakanlığının hazırlamış olduğu Türkçe öğretim programı çerçevesinde farklı yayınevlerinin hazırlamış olduğu ders kitapları ile yürütülmektedir. Okuduğunu anlamayı değerlendirici çalışmalar da, sıklıkla kitaplardaki metin soruları ile yapılmaktadır. Bu yüzden ders kitaplarındaki soruların; öğrencilerin okumaya olan merakı ve ilgiyi sağlama, eski ve yeni bilgilerini bütünleştirme ve üst düzey düşünebilme gibi bir takım becerileri geliştirmeye dönük olması beklenmektedir. Araştırmadan elde edilen sonuçların, bundan sonra hazırlanacak ders kitaplarına bakış açısı sunması beklenmektedir.

\section{Kaynaklar}

Aktaş, E. (2017) Öğretmen Adaylarının Farklı Metin Türlerine yönelik Soru Sorma Becerilerinin Yenilenmiş Bloom Taksonomisine Göre Değerlendirilmesi

Akyol, H. (1996) Metinler arası (Intertextuality) okuma ve sorular. Bilgi Çağında Eğitim, 7, 8-11.

Akyol, H. (1997). Okuma metinlerindeki soruların sınıflandırılması. Eğitim ve Bilim, 21, 10-17.

Akyol, H. (2001). illköğretim okulları 5. sınıf Türkçe kitaplarındaki okuma metinleriyle ilgili soruların analizi. Kuram ve Uygulamada Eğitim Yönetimi, 26, 169-178.

Akyol, H. (2011). Yeni programa uygun Türkçe öğretim yöntemleri. Ankara: Pegem Akademi Yayınları.

Akyol, H., Yıldırım, K., Ateş, S. ve Çetinkaya, Ç. (2013). Anlamaya yönelik nasıl sorular soruyoruz?. Mersin Üniversitesi Eğitim Fakültesi Dergisi, 9(1), 41-56.

Applegate, M. D. (2007). Teacher's use of comprehension questioning to promote thoughtful literacy. Journal of Reading Education, 32(3), 12-19.

Applegate, M. D., Quinn, K. B. ve Applegate, A. J. (2002). Levels of thinking required by comprehension questions in informal reading inventories. The Reading Teacher, 56, 174-180.

Aslan, C. (2011). Soru sorma becerilerini geliştirmeye dönük öğretim uygulamalarının öğretmen adaylarının soru oluşturma becerilerine etkisi

Ateş, S., Güray, E., Döğmeci, Y. ve Gürsoy, F. F. (2016). Öğretmen ve öğrenci sorularının gerektirdikleri zihinsel süreçler açısından karşılaştııılması/Comparison of questions of teachers and students in terms of level. Okuma Yazma Eğitimi Araştırmaları, 4(1), 1-13.

Aydemir, Y. ve Çiftçi, Ö. (2008). Edebiyat öğretmeni adaylarının soru sorma becerileri üzerine bir araştırma. Yüzüncü Yıl Üniversitesi, Eğitim Fakültesi Dergisi, 5, 103-115. 


\section{1.-8. Sınıf Türkçe Ders Kitaplarındaki Metne Dayalı Anlama Sorularının İncelenmesi}

Barrett Taksonomisi Dokümanı ${ }^{1}$. Cognitive and Affective Dimensions of Reading Comprehension. Internetten 29 Kasım 2018 'de http://joebyrne.net/curriculum/barrett.pdf adresinden alınmıştır.

Barrett, T. C. (1968). Taxonomy of cognitive and affective dimensions of reading compre hension. Discussed by Clymer, T. in "What is reading?": some current concepts. Helen M. Robinson (Ed.). Innovation and change in reading instruction. Sixty-seventh yearbook: National Society for Study in Education, University of Chicago Press, 1-30.

Bloom, B. S. (1956). Taxonomy of education objectives. The Classification of Educational Goals. Handbook I: Cognitive Domain. New York, NY: McKay.

Bozkurt B. Ü., Uzun G. L., Lee Y. H. (2015). Korece ve Türkçe ders kitaplarındaki metin sonu sorularının karsılastırılması: PISA 2009 sonuçlarına dönük bir tartısma. IJLA, 3(9), 295313.

Clymer, T. (1968). What is "reading"? some current concepts. H. Richie ve H. Robinson (Eds.), Innovations and change in reading instruction (s. 7-29). Chicago: National Society for the Study of Education.

Çeçen, M. A. ve Kurnaz, H. (2015). Ortaokul Türkçe dersi öğrenci çalışma kitaplarındaki tema değerlendirme soruları üzerine bir araştırma. Karadeniz Sosyal Bilimler Dergisi, 7(02).

Çelik, T., Demirgüneş, S. ve Fidan, D. (2015). Okur dostu metin olma özelliği ile okuduğunu anlama başarısı arasındaki ilişkinin incelenmesi. Başkent University Journal of Education, 2(1), 115-122.

Day, R. R. ve Park, J. (2005). Developing reading comprehension questions. Reading in a Foreign Language, 17(1), 60-73.

Duke, N. ve Carlisle, J. F. (2011). Comprehension development. Handbook of reading research, 4, $199-228$.

Durukan, E. (2009). 7. Sınıf Türkçe ders kitaplarındaki metinleri anlamaya yönelik sorular üzerine taksonomik bir inceleme. Milli Ĕğitim, 181, 84-93.

Eroğlu, D. ve Sarar Kuzu, T. (2014). Türkçe ders kitaplarındaki dilbilgisi kazanımlarının ve sorularının yenilenmiş Bloom taksonomisine göre değerlendirilmesi. Başkent University Journal of Education, 1(1), 72-80.

Fordham, N. W. (2006). Strategic questioning. Principal Leadership, 7, 33-37.

Göçer, A. (2014). The Assessment of Turkish written examination questions based on the text in accordance with the Barrett's Taxonomy. International Journal of Languages' Education and Teaching, 3, 1-16.

Guthrie, J. T. (2004). Teaching for literacy engagement. Journal of Literacy Research, 36(1), 1-29.

Guthrie, J. T. ve Taboada, A. (2004). Fostering the cognitive strategies of reading comprehension. J. T. Guthrie, A. Wigfield, ve K. C. Perencevich (Eds.), Motivating reading comprehension: Concept-oriented reading instruction (s. 87-112). Mahwah, NJ: Lawrence Erlbaum.

Güfta, H. ve Zorbaz, K. Z. (2008). İlköğretim ikinci kademe Türkçe dersi yazılı sınav sorularının düzeyleri üzerine bir değerlendirme. Çukurova Üniversitesi Sosyal Bilimler Enstitü Dergisi, 17, 205-218.

Hervey, S. (2006). Who asks the questions? Teaching PreK-8, 37, 68-69.

Keray, B. ve Güden, Z. (2013). The analysis of students' skills of asking questions through informative texts. Sakarya University Journal of Education, 3(1), 9097.

Kintsch, W. ve Rawson, K.A. (2005) The acquisition of reading comprehension skill. Snowling, M. J., ve Hulme, C. (Eds.). The science of reading: A handbook (s. 209-226). UK: Blackwell Publishing.

Klingner, J. K. (2004). Assessing reading comprehension. Assessment for effective intervention, 29(4), 59-70.

Kocaarslan, M. ve Yamaç, A. (2018). Sınıf öğretmenlerinin Türkçe dersi sınavlarında sordukları metne dayalı anlama sorularının incelenmesi. Trakya Üniversitesi Eğitim Fakültesi Dergisi, 8(2), 431-448.

Krippendorff, K. (1995). On the reliability of unitizing continuous data. Sociological Methodology, 25, 47-76. Accessed: $30-11-2018$ 
Kutlu, Ö. (1999). İlköğretim okullarındaki Türkçe ders kitaplarındaki okuma parçalarına dayalı olarak hazırlanmış sorular üzerine bir inceleme. Eğitim ve Bilim Dergisi, 23 (111), 14-21.

Kuzu, T. S. (2013). Türkçe ders kitaplarındaki metin altı sorularının yenilenmiş Bloom taksonomisindeki hatırlama ve anlama bilişsel düzeyleri açısından incelenmesi, CÜ Sosyal Bilimler Dergisi, 37(1), 58- 76.

Lah, Y. C. ve Hashim, N. H. (2014). The acquisition of comprehension skills among high and low achievers of year 4 to 6 students in primary School. Procedia-Social and Behavioral Sciences, 114, 667-672.

MEB (2018). Türkçe Ders Kitabı (1.,3.,4.,5.,6.,7.,8. sınıf). Ankara: Milli Eğitim Bakanlığı Yayınları.

MEB (2018). Türkçe Ders Kitabı (2. sınıf). Ankara: Koza Yayınları.

Milli Eğitim Bakanlığı (2018). Türkçe Dersi Öğretim Programı (ilkokul ve Ortaokul 1, 2, 3, 4, 5, 6, 7 ve 8. Sınıflar). Internetten $17 \quad$ Ocak $2019 \quad$ http://mufredat.meb.gov.tr/Dosyalar/201812312239736T\%C3\%BCrk\%C3\%A7e\%20\%C3\%96\%C4\%9Fretim\%20Program\%C4\%B1\%202018.pdf adresinden alınmıştır.

Nicholas, D. W. ve Trabasso, T. (1980). Toward a taxonomy of inferences for story comprehension. Information integration by children, 243-265.

Parker, M. ve Hurry, J. (2007). Teachers' use of questioning and modelling comprehension skills in primary classrooms. Educational Review, 59(3), 299-314.

Pearson, P.D. ve Johnson, D.D. (1978). Teaching reading comprehension. New York: Holt Rinehart and Winston.

Rosenblatt, L. M. (1978). The reader, the text, the poem: The transactional theory of literacy work. Carbondale, IL: Southern Illinois University Press

Ruddell, R. B. (1978). Developing Comprehensive Abilities: Implications From Research for an Instructional Framework. Educational Perspectives, 17(1), 8-13.

Sanders, N. M. (1966). Classroom questions: What kinds? New York, N.Y.: Harper \& Row.

Savaşkan, V. (2016). Ortaöğretim 9. sınıf Türk Edebiyatı ders kitaplarındaki metin altı soruları üzerine bir inceleme. Hitit Üniversitesi Sosyal Bilimler Enstitüsü Dergisi, 9(2), 821-836.

Sever, S. (2008). Eğitimde ve bilimde Türkçe. Türkiye Cumhuriyeti'nin Kuruluşunun 100'üncü Yılında Eğitim Kurultayı (s.435-471). Malatya: İnönü Üniversitesi Yayınları.

Ülper, H. ve Yalınkılıç, K. (2010). Son iki Türkçe programına göre hazırlanan Türkçe ders kitaplarındaki metin sonu sorularının nicel ve nitel görünümü. Uluslararası Sosyal Araştırmalar Dergisi, 3(12), 449-461.

Wallen, C. (1972). Comprehension Skills. Competency in Teaching Reading. Chicago, III.: Science Research Associates, Inc.

Wang, J. H. ve Guthire, T. J. (2004). Modeling the effect of intrinsic motivation, extrinsic motivation, amount of reading, and past reading achievement on text comprehension between U.S. and Chinese students. Reading Research Quarterly, 39, 2, 162-186.

Wixson, K. K. (1983). Questions about a text: What you ask about is what children learn. The Reading Teacher, 37, 287-293.

Yıldııım, A. ve Şimsek, H. (2008). Sosyal bilimlerde nitel araştırma yöntemleri. (7. Baskı). Ankara: Seçkin Yayıncılık.

Yıldırım, K. (2012). Öğretmenlerin Öğrencilerin Okuduğunu Anlama Becerilerini Değerlendirmede Kullanabilecekleri Bir Sistem: Barrett Taksonomisi. Mustafa Kemal Üniversitesi Sosyal Bilimler Enstitüsü Dergisi, 9(18), 45-58.

\section{Extended Abstract \\ Introduction}

Reading together with reading comprehension are the basic skills that should be acquired during primary school. According to Akyol (2011), the reason why reading and reading comprehension skills are included in education programs is to add meaning to human life. From this point of view, reading and reading 


\section{1.-8. Sınıf Türkçe Ders Kitaplarındaki Metne Dayalı Anlama Sorularının İncelenmesi}

comprehension can be seen as important skills that cannot be limited to school life or academic achievement and that affect every aspect of life. How the comprehension skills will be measured has been an important area of study for researchers. There are various studies in the literature on how comprehension questions are formed and in what framework these questions are asked. Barrett (1968) listed the taxonomy he developed according to the difficulty level of the questions in five steps: literal comprehension, reorganization, inferential comprehension, evaluation and appreciation.

Many research examined the questions used in evaluating the reading comprehension in the relevant literature (Aktaş, 2017; Akyol, 1997, 2001; Akyol, Yildirim, Ates, and Cetinkaya, 2013; Applegate, 2007; Bozkurt, Uzun and Lee, 2015; Durukan, 2009; Göçer, 2014; Güfta and Zorbaz, 2008; Kocarslan and Yamac, 2018; Klingner, 2004; Parker and Hurry, 2007; Savaşkan, 2016; Ülper and Yalinkılıc, 2010; Yildirim, 2012). Studies on the classification of reading comprehension questions in Turkey were found to be mostly based on Bloom's taxonomy (Aktaş, 2017; Aydemir and Çiftçi, 2008; Çeçen and Kurnaz, 2015; Güfta and Zorbaz, 2010; Keray and Güden, 2013; Kuzu, 2013). There are also studies examining the classifications of the questions based on Barrett's taxonomy (Akyol, Yildirim, Ateş and Çetinkaya; 2013; Ateş, Güray, Döğmeci and Gürsoy, 2016; Çelik, Demirgüneş and Fidan, 2015; Göçer, 2014; Yildirim, 2012). However, in the relevant literature, text-based comprehension questions in Turkish textbooks through Barrett's taxonomy have never been examined. It is considered that examining and evaluating the text questions in Turkish textbooks based on this taxonomy will provide not only information about the nature of the questions in the current textbooks but also provide suggestions for the questions in the books to be prepared thereafter. In this sense, the aim of the study is to examine the text-based comprehension questions in Turkish textbooks from the 1st to the 8th grade. For this purpose, the following questions were sought in the research.

\section{Method}

The data of the study which was structured on qualitative approach were obtained through document review. Materials included Turkish textbooks prepared by Ministry of National Education to be used for the $1^{\text {st }}$ to the $8^{\text {th }}$ grade in 2018-2019 academic year. 960 text-based comprehensions questions of 179 texts were analyzed.

\section{Results and Discussion}

Firstly, approximately half of the text types in Turkish textbooks were narrative (49.7\%), and the rest were informative $(28.5 \%)$ and poetry $(21.7 \%)$ texts. Findings primarily indicated that approximately half of the text types in Turkish textbooks were narrative $(49.7 \%)$, and the rest were informative $(28.5 \%)$ and poetry $(21.7 \%)$ texts. In line with this finding, it was determined that the most frequent questions were from narrative text type.

Secondly, it was found out that most of the text-based comprehension questions in Turkish textbooks included intratextual questions (78.3\%), extratextual questions ranked as the second (21.7\%). As for intertextual questions, they were never asked. The results of the study are similar to the findings of Akyol (2001) in his study examining the questions related to reading texts in the $5^{\text {th }}$ grade Turkish textbooks in which approximately $97 \%$ of the post-text questions were intertextual questions.

Thirdly, it was revealed that while the majority of the text-based comprehension questions were just literal comprehension questions $(66.8 \%)$, very few of them were reorganization $(10,4 \%)$, inferential comprehension $(8,8 \%)$, evaluation $(12,6 \%)$ and appreciation $(1,4 \%)$ questions. The findings obtained from this study were found to correspond with the findings obtained from various research for the classification and evaluation of the text-based comprehension questions asked in the Turkish course (Aktaş, 2017; Akyol, Yildirim, Ateş and Çetinkaya, 2013; Aslan, 2011; Ateş, Güray, Döğmeci and Gürsoy, 2016; Aydemir and Çiftçi 2008; Çeçen and Kurnaz, 2015; Durukan,2009; Eroğlu and Sarar Kuzu, 2014; Güfta ve Zorbaz, 2008; Kocaarslan and Yamaç, 2018; Kutlu, 1999; Ülper and Yalınkıııç, 2010). 